\title{
Insurance Products in Rastin Profit and Loss Sharing Banking
}

\author{
Bijan Bidabad $^{1}$
}

\begin{abstract}
Purpose: This paper aims to explain new insurance products and policies in Rastin Profit and Loss Sharing (PLS) Banking. Rastin Banking is a full Islamic Banking System with all necessary parts for banking operations that can be installed in conventional and Islamic banks both. In this paper, we are going to explain the milestones of new insurance products and policies.

Design: Rastin Banking complies with the nature of the intermediary financial activity and has a new type of banking operations. The systems and instruments of this type of banking have different risk treatments, and new insurance policy and measures should be defined to cover the risks of the operations In order to fulfill this goal, appropriate insurance policies are described.

Findings: Some new insurance products are defined such as Certificate Insurance, Insurance of Market Value of Certificate, Responsibility/Engineering Insurance, Insurance of Accidents Concerning the Article of Sharing, Collateral Insurance, Loss Margin Insurance, Profit Margin Insurance, Merchandise Transportation Insurance, Production Equipment and Installations Insurance, Product Quality Insurance, Insurance of Commodity under Production, Inventory Insurance, Production Limited Loss Insurance, Transaction Limited Loss Insurance to handle Rastin Banking.

Research limitations: Many of these insurance policies are new and require more elaborations for further practical development and adjustment.

Practical implications: These insurance products can be used both in Rastin Banking operations as well as conventional business and finance arrangements. These insurance policies have no conflict with indisputable legal principles, and insurance companies can supply these insurance products based on their own actuary calculations.

Social implications: The introduced insurance policies actually change profit and loss sharing activity to just profit sharing.

Originality/value: Approach of this system and the designed insurance policies is entirely different and new.
\end{abstract}

Article Type: Technical paper

Keywords: Rastin Banking, Profit and Loss Sharing (PLS), Insurance, Insurance Products, Insurance policy, Islamic banking

\section{Introduction}

Insurance in Persian is called "Bimah" derived from the word "Bima", and has Sanskrit $\operatorname{root}^{2}$ and also has the same root of the verb "Bim" (to fear) in Persian. Some others believe that this term comes from the translation of a Russian word of "Astrakhan" from a philological point of view that means as opposite of fear; this is because Russians introduced insurance in Iran for the first time. Some others believe "Bimah" is the name of a town in Tabaristan and Deilam. ${ }^{3}$

Daily applied the meaning of Bimah is the organized grouped guarantee or coverage for facing the aftermaths of perils and losses or future unwelcoming events in socioeconomic life. Insurance is defined as a contract according to which the insurer underwrites to indemnify another (insured person) in the event of loss or damage. An insurer is a person or company offering insurance policies in return for premiums. An insured person is a person whose interests are protected by an insurance policy. On the other hand, he is an individual who contracts for an insurance policy that indemnifies him against loss of property or life or health, etc. (insured article). ${ }^{4}$ In other words, the insurer and

\footnotetext{
${ }^{1}$ (B.A., M.Sc., Ph.D., Post-Doc.) Professor of Economics and Chief Islamic Banking Advisior, Bank Melli Iran. http://www.bidabad.com bijan@bidabad.com

${ }^{2}$ Moin, Mohammad (1971) Moin Persian Dictionary. AmirKabir Publishing Institute. In Persian.

${ }^{3}$ Salehi, Jan Ali Mahmoud, (2002). Insurance law. Bimeh Markazi, Iran. Training and Publication Department. In Persian.

${ }^{4}$ http://www.thefreedictionary.com/insurance
} 
the insured person will transact and share the costs of a particular risk of the item insured. ${ }^{5}$

\section{Insurance Products}

Economic/business insurances have a long previous record of about 6500 years. According to discovered Papyrus, stonecutters of ancient Egypt had established a joint fund to protect themselves in the case of an accident. Hammurabi, the king of Babylon, enacted a law in which those in charge of transportation were responsible for the safeguarding of merchandises in $2250 \mathrm{BC}$. Also, in Greece, there were associations, which helped their members who paid fees to an established fund if they had suffered any loss in 588-640 BC. Similar activity has also been seen in ancient Rome. ${ }^{6}$ Many similar activities have also been observed in medieval times. ${ }^{7}$ Business insurances today are as more or less in the following context:

1. Life insurance

2. Personal accident insurance

3. Medical and Medicare insurance

4. Fire insurance and subordinate dangers such as explosion, theft, earthquake, flood, air crash and even terrorist attack

5. Transportation insurance

6. Civil responsibility of transportation means (marine, air and land transports)

7. General responsibility (legal and professional) insurance

8. Full risk coverage insurance of contractual works, installing and related civil responsibly

9. Money in the fund and in action insurance

10. Staff's honesty and trust insurance

11. Oil exploration and extraction and related industries insurances

12. Agricultural products insurance

13. Export insurances

In all the above-mentioned insurances, by receiving insurance fee, the insurer will provide financial risk coverage for the insured person about the article insured.

\section{Risk Nature in Rastin Banking Operations and Instruments}

Rastin Profit and Loss Sharing is an activity in Rastin Banking ${ }^{8}$ and is based on the participation of depositors ${ }^{9}$ in economic activity and investment of entrepreneur ${ }^{10}$ based on the real yield of projects in order to land real interestfree banking according to Islamic commandments and ethics. In Rastin Profit and Loss Sharing (PLS) Banking, the bank is a unit, which after assessment ${ }^{11}$ of the project proposal ${ }^{12}$; allocates resources from depositors to the project ${ }^{13}$

\footnotetext{
${ }^{5}$ See: Mehr, Robert I., (1985) Principles of Insurance. Richard D Irwin; $8^{\text {th }}$ edition.

Vaughn, Emmett J.(1989) Fundamentals of Risk and Insurance. $5^{\text {th }}$ edition, Wiley.

${ }^{6}$ Salehi, JanAli Mahmoud, (2002). Insurance Act, Bimeh Markazi Iran. Training and Publication Department. In Persian, pp. 6573.

${ }^{7}$ Various insurances, at least, commercial insurances were used in Arabian Peninsula before Islam. This may be the reason why the holy Prophet has not mention about it explicitly because he only entered economic subjects whenever necessary.

${ }^{8}$ Rastin Banking is operational true Islamic bank

Bidabad, Bijan. (2014). New Operational Islamic Banking System, Volume One, Theoretical Foundations, LAP Lambert Academic Publishing, OmniScriptum GmbH \& Co. KG, ISBN: 978-3-659-54463-7.

Bidabad, Bijan. (2014). New Operational Islamic Banking System, Volume Two, Applicational Issues, LAP Lambert Academic Publishing, OmniScriptum GmbH \& Co. KG, ISBN: 978-3-659-55210-6.

${ }^{9}$ Depositor is a real person or legal entity with a certain amount of fund (cash) requests Rastin PLS bank to participate in Rastin PLS Banking products through direct contact with Rastin PLS bank, or via internet and purchases Rastin Certificate of one of the Rastin PLS Banking products of a project.

${ }^{10}$ Entrepreneur is a real person or legal entity who proposes a project to PLS bank for financing through PLS banking system and executes the project until the end. In addition to have legal, financial, technical and performance capabilities, the entrepreneur should have the other capabilities and facilities/possibility to carry out the job.

${ }^{11}$ Assessments are actions which are done by bank for protection of depositor's interests, identification of the entrepreneur's skills, and economic, financial, executive, and technical justifiability of the concerned project in Rastin Banking.

${ }^{12}$ Project Proposal: is a written document covering a collection of necessary information about the proposed project that describes analytical justification of the project from economic, technical and financial points of view, with enclosed necess ary legal licenses and documents; which is submitted to Rastin PLS bank by entrepreneur. After evaluation of the bank if be
} 
of those looking for financing (entrepreneur) and according to contract; the obtained profit or loss is divided between depositor and entrepreneur. By receiving a commission, the bank provides capital management services for depositors, and invest their financial resources according to their choices and in return, provides them by Rastin Certificate. The bank should use all his specialized potentialities to protect depositors' rights. So the bank starts monitoring ${ }^{14}$ the project by the trustee unit ${ }^{15}$ of the PLS office ${ }^{16}$.

Rastin PLS Base system ${ }^{17}$ is the primary process and includes the general rules of Rastin Profit and Loss Sharing Banking system. Rastin Financial Subsystems refer to specific financing methods or services in Rastin PLS Banking. These subsystems work under general regulations of Rastin PLS Base system, and most of the rules of Rastin PLS Base system are extended to its financial subsystems as well. These subsystems have their own financial and regulatory processes and are as follows:

a. Joalah Financial Sharing (JFS) $)^{18}$

b. Mudarabah Financial Sharing (MFS) ${ }^{19}$

c. Installment Financial Sharing (IFS) ${ }^{20}$

d. Rent Financial Sharing (RFS) ${ }^{21}$

e. Bail Financial Sharing (BFS) ${ }^{22}$

f. Rastin Group Funding (RGF) ${ }^{23}$

g. Rastin Personal Security (RPS) $)^{24}$

h. Rastin Social Takaful l $^{25}(\mathrm{RST})^{26}$

approved, proposal will be a reference source against entrepreneur executive operations.

${ }^{13}$ Project is a collection of economic activities with specified and concrete plan with defined cost and terms for making profit through Rastin PLS Banking offered to PLS bank.

${ }^{14}$ Monitoring is an action which is done by bank for protection of depositor's interests and good performance of executive operation in Rastin Banking. Bank is obliged to take measures for good operational performance. Standards for monitoring are based on Rastin Banking articles of the executive bylaw.

${ }^{15}$ Trustee unit is a unit at PLS office of Rastin PLS bank for supervision and control of Rastin PLS proposed projects on behalf of bank regarding good performance of project in comparison to initial proposal through key indicators and financial reports and supervision for final delivery of the project.

${ }^{16}$ PLS Office: It is a bank department that along with subordinate units manages participation processes in Rastin Banking.

${ }^{17}$ Bidabad, Bijan (2013) Rastin Profit and Loss Sharing (PLS) Base System. Journal of Islamic Economics, Banking and Finance, pp. 32-57, Vol. 9 No. 4, Oct - Dec.

http://ibtra.com/pdf/journal/v9_n4_article2.pdf

${ }^{18}$ Bijan Bidabad, Joalah Financial Sharing (JFS). Journal of Islamic Economics, Banking and Finance, Volume-12, No. 1, January-March, 2016, pp. 33-48.

http://www.bidabad.com/doc/jfs-paper-en.pdf http://ibtra.com/pdf/journal/v12_n1_article2.pdf

${ }^{19}$ Bidabad, Bijan, Mudarebah Financial Sharing (MFS). Journal of Islamic Economics, Banking and Finance, JIEBF, Volume - 10, Number - 1, January - April 2014, pp. 56-68.

http://www.bidabad.com/doc/mfs-paper-en.pdf

http://ibtra.com/pdf/journal/v10_n1_article3.pdf

${ }^{20}$ Bidabad, Bijan, Instalment Financial Sharing (IFS). Journal of Islamic Economics, Banking and Finance, 2014. http://www.bidabad.com/doc/ifs-paper-en.pdf

${ }^{21}$ Bidabad, Bijan, Rent Financial Sharing (RFS). Journal of Islamic Economics, Banking and Finance, 2014. http://www.bidabad.com/doc/rfs-paper-en.pdf

http://ibtra.com/pdf/journal/v10_n2_article2.pdf

22 Bidabad, Bijan, Bail Financial Sharing (BFS). Journal of Islamic Economics, Banking and Finance, 2014.

http://www.bidabad.com/doc/bfs-paper-en.pdf

${ }^{23}$ Bijan Bidabad, Rastin Group Funding (RGF). Bank Melli Iran, Tehran, 2014.

http://www.bidabad.com/doc/rgf-paper-en.pdf

${ }^{24}$ Bidabad, Bijan, Rastin Personal Security (RPS). Journal of Islamic Economics, Banking and Finance, JIEBF,

Volume - 11, Number - 2, April - June 2015, pp. 47-61.

http://ibtra.com/pdf/journal/v11_n2_article3.pdf

http://www.bidabad.com/doc/rps-paper-en.pdf

${ }^{25}$ Takaful: is the humanistic duty of the society to fulfill the basic needs of the individuals and is devided into two parts:

Public Takaful: is the humanistic duty of the individuals to fulfill other propels' needs. Zeman Ialah: is the duty of the 
i. $\quad$ Sponsor Crowd Funding $(\mathrm{SCF})^{27}$

j. $\quad$ Peer to Peer Loan (PPL) ${ }^{28}$

k. Rastin Swap Bond (RSB) $)^{29}$

1. Rastin Swap Deposit (RSD) $)^{30}$

m. Rastin Swap Card (RSC) ${ }^{31}$

Rastin Certificates is a collection of designed certificates in Rastin PLS Banking Base system and its financial subsystems. These certificates are issued and delivered to depositor or financer instead of the received fund (deposit). Rastin Certificates (except Guarantee Certificate) are transferable and negotiable online through the Rastin Certificate Market (RCM) ${ }^{32}$ of the bank and are issued with a nominal price and for a specified period. The owners of these certificates share the results of the project proportional to nominal price and participation period of the certificate. Various Rastin Certificates and their characteristics according to the kind of participation in the PLS Base system or its financial subsystems regarding the type of project and the used asset will be bound to Rastin Banking regulations. These certificates can be anonymous or named papers, except Guarantee Certificate that must be named. These certificates are:

1- Partnership (Musharakah) Certificate: is an anonymous or named paper which expresses the participation of depositor in one of the PLS banking products with a defined value and is issued by bank for a specified period and its owner shares the profit and loss of the subject of participation proportional to its nominal value and duration of participation according to rules and regulations of Rastin PLS Banking. This certificate is used in Rastin PLS Base System.

2- Subscripted (Pazireh) Certificate: is an anonymous or named paper which expresses the participation of depositors in one of the first or second kinds of PLS banking products with a defined value which is issued by bank for construction period for infinitude projects and its owner shares the profit and loss of the subject of participation proportional to its nominal value and duration of participation by becoming the shareholder of the company according to rules and regulations of Rastin PLS Banking. This certificate is used in Rastin PLS Base System.

3- Future Certificate: is an anonymous or named paper that cites a commitment to deliver the commodity that is issued by the bank and can be negotiated and transferred to another purchaser. By this certificate, the entrepreneur or producer is committed to delivering the commodity to the certificate holder at maturity or sales the commodity and refund the sold amount to financer according to the contract. This certificate is used in Joaleh Financial Sharing (JFS) subsystem.

government to provide the sustenance of the individuals in the society.

${ }^{26}$ Bidabad, Bijan, Rastin Social Takaful (RST). Journal of Islamic Economics, Banking and Finance, JIEBF,

Volume - 11, Number - 1, January - March 2015, pp.: 13-23.

http://ibtra.com/pdf/journal/v11_n1_article1.pdf

http://www.bidabad.com/doc/rst-paper-en.pdf

${ }^{27}$ Bidabad, Bijan, Rastin Crowd Funding, 2014.

http://www.bidabad.com/doc/rcf-paper-en.pdf

${ }^{28}$ Bidabad, Bijan, Rastin Crowd Funding, 2014.

http://www.bidabad.com/doc/rcf-paper-en.pdf

${ }^{29}$ Bidabad, Bijan, Abul Hassan, Ben Ali Mohamed Sami, Mahmoud Allahyarifard. Interest-Free Bonds and Central

Banking Monetary Instruments. International Journal of Economics and Finance. Vol. 3, no. 3, Aug 2011, pp.234-

241.

http://www.ccsenet.org/journal/index.php/ijef/article/download/11665/8300

Bidabad, Bijan, Abul Hassan, Ben Ali Mohamed Sami, Mahmoud Allahyarifard. Interest-Free Bonds Financial

Innovation, A Monetary Instrument for Economy at Crisis. Journal of Economic Cooperation and Development

(JECD). 32, 1, 2011, 55-70.

http://www.sesric.org/jecd/jecd_articles/ART10102201-2.pdf

${ }^{30}$ Bijan Bidabad, Rastin Swap Deposit. Tehran, 2015.

http://www.bidabad.com/doc/rsd-paper-en.pdf

${ }^{31}$ Bijan Bidabad, Rastin Swap Card. Tehran, 2015.

http://www.bidabad.com/doc/rsc-paper-en.pdf

${ }^{32}$ Rastin Certificate Market is a web-based settlement system for transaction and transfer of Rastin Certificates and valuable papers of Rastin bank. 
4- Mudarabah Certificate: is an anonymous or named paper which expresses the participation of depositor in profit and loss of a particular project (Product I) of the PLS banking products with a defined value and is issued by bank for specified period and its owner shares the profit and loss of the subject of participation proportional to its nominal value and duration of participation according to rules and regulations of Rastin PLS Banking. This certificate is used in Mudarabah Financial Sharing (MFS) subsystem.

5- Periodic Mudarabah Certificate: is the same as Mudarabah Certificate, but the return of the project is paid to depositor periodically. This certificate is used in Mudarabah Financial Sharing (MFS) subsystem.

6- Mughasatah Certificate: is an anonym negotiable document issued by Rastin PLS bank with a nominal price for real financial participation (sharing) for a specified period. The bearer of this paper receives periodic payments relative to his share and the period of participation. Payments will be paid at the end of each period. In the end, the entrepreneur will own the project. This certificate obtains installment until the end of the contract, and after the settlement of the contract, the entrepreneur becomes the owner of the project. The settlement is after the payout of the last installment. This certificate is used in Instalment Financial Sharing (IFS) subsystem.

7- Rental Mughasatah Certificate: is an anonym negotiable document with a defined nominal price for a defined period of time (rental tenure) issued by Rastin PLS bank, which conducts Rastin PLS activity. The owners of these certificates have right on the results of the sharing project which is proportional to the nominal value of the certificate and the duration of holding certificate until the end and receive periodic rent and installment of the valuation of the project at the end of each period. The settlement is after the payout of the last installment and rents for the certificate. At the end of the contract, the entrepreneur will become the owner of the project. This certificate is used in Instalment Financial Sharing (IFS) subsystem.

8- Musharakah Mughasatah Certificate: is an anonym negotiable document with a defined nominal price for a defined period of time (Musharakah tenure) issued by Rastin PLS bank, which conducts PLS activities. The owner of this certificate has right on the result of the sharing project proportional to the nominal value of the certificate and the duration of holding the certificate until the end of the contract, and receive periodic installment plus income (positive/negative) yields of the project at the end of each period. After the payout of the last installment and the profit or loss (yield), the settlement takes place. In the end, the entrepreneur will become the owner of the project. This certificate is used in Instalment Financial Sharing (IFS) subsystem.

9- Mortgage Sharing Certificate: is an anonym (nameless) negotiable document with a nominal price, which is issued for a specified period by a Rastin PLS bank. The holder of these certificates shares in the yield of the asset of the project proportional to his share to the nominal price of the assessed value of the asset considering his participation period. The principal and return of sharing of these certificates will be paid to the depositor at the end of the contract. This certificate is used in Rent Financial Sharing (RFS) subsystem.

10- Periodic Mortgage Sharing Certificate: is the same as Mortgage Sharing Certificate, but the return of the certificate is periodically paid to the certificate holder. This certificate is used in Rent Financial Sharing (RFS) subsystem.

11- Mortgage Mudarabah Certificate: is similar to Mortgage Sharing Certificate, but this certificate is used for commercial financing services. This certificate is used in Rent Financial Sharing (RFS) subsystem.

12- Periodic Mortgage Mudarabah Certificate: is similar to Periodic Mortgage Sharing Certificate, but this certificate is used for commercial financing services. This certificate is used in Rent Financial Sharing (RFS) subsystem.

13- Mortgage Muzaraah Certificate: is similar to Mortgage Mudarabah Certificates but for agricultural financing. This certificate is used in Rent Financial Sharing (RFS) subsystem.

14- Periodic Mortgage Muzaraah Certificate: is similar to Periodic Mortgage Mudarabah Certificate but for agricultural financing. This certificate is used in Rent Financial Sharing (RFS) subsystem.

15- Mortgage Mugharasah Certificate: is similar to Mortgage Muzaraah Certificate but for planting and restoring tree gardens financing. This certificate is used in Rent Financial Sharing (RFS) subsystem.

16- Periodic Mortgage Mugharasah Certificate: is similar to Periodic Mortgage Muzaraah Certificate but for planting and restoring tree gardens financing. This certificate is used in Rent Financial Sharing (RFS) subsystem. 
17- Mortgage Musaqah Certificate: is similar to Mortgage Muzaraah Certificate but for maintaining and harvesting fruit gardens financing. This certificate is used in Rent Financial Sharing (RFS) subsystem.

18- Periodic Mortgage Musaqah Certificate: is similar to Periodic Mortgage Muzaraah Certificate but for maintaining and harvesting fruit gardens financing. This certificate is used in Rent Financial Sharing (RFS) subsystem.

19- Mortgage Istisna Certificate: is similar to Mortgage Muzaraah Certificate but for financing industrial and agricultural firms. This certificate is used in Rent Financial Sharing (RFS) subsystem.

20- Periodic Mortgage Istisna Certificate: is similar to Periodic Mortgage Muzaraah Certificate but for financing industrial and agricultural firms. This certificate is used in Rent Financial Sharing (RFS) subsystem.

21- Rent Certificate: is an anonym negotiable document, which is issued with a defined nominal price and for a certain period by Rastin PLS bank. The owner of this certificate shares the rent of asset proportional to its assessed asset nominal price. The rent will be paid to depositor periodically, but the original fund plus the rent will be paid to the depositor at the end of the contract period. This certificate is used in Rent Financial Sharing (RFS) subsystem.

22- Guarantee Certificate: is a named document which shows the guarantee of a certain amount of money and is issued by notary upon the mortgaged asset and if the obligation is not fulfilled, the owner must compensate it. Otherwise, the mortgaged asset will be sold through auction, and the claim of the acceptor will be settled. This certificate is used in Mortgage Securitization System (MSS).

23- Bail Certificate: is an anonym negotiable paper with a defined face value and duration issued by Rastin PLS bank branch. The owner of this certificate will receive the commodity or its price (at market price) from the entrepreneur who is obliged for this certificate. This certificate is used in Bail Financial Sharing (BFS) subsystem.

24- Social Security Certificate: is an anonym or named negotiable document with defined nominal price issued and for a specified period given to the insured person by Rastin PLS bank on behalf of the security fund in exchange for payment of insurance premium to the security fund. The holder of this certificate shares the fund capital proportionate to the value and shares the fund returns proportionate to the amount and duration of his certificate. This certificate is used in Rastin Personal Security (RPS) subsystem.

25- Personal Security Certificate: is an anonym or named negotiable document with defined nominal price and maturity, and is issued by Rastin PLS bank on behalf of the pension fund for depositor by the request of the pension fund and equal to the amount of the deposited deposit. The holder of this certificate shares the capital of the fund in proportion to his deposit and shares the return of the pension fund proportional to the amount and duration of the deposit and receives his share (principal and profit) from the fund at maturity. This certificate is used in Rastin Personal Security (RPS) subsystem.

26- Pension Security Certificate: is an anonym or named negotiable document, which is issued from changing the share of the depositor into several small lots at maturity, so that the holder can receive continuous pension payments from the fund. The return of this certificate will be calculated and paid to depositor according to Rastin Participation Accounting procedures for Joint Stock Company with Variable Capital (JSCVC). ${ }^{33}$ On the other hand, if depositor or the owner of the certificate does not want to receive back his share and return from the fund in a lump sum at maturity, he can ask the fund to change his certificate into several smaller certificates with continual maturities and amounts via the agent bank. This certificate is used in Rastin Personal Security (RPS) subsystem.

27- Takaful Certificate: is an anonym or named negotiable document with a defined face value and term, which is issued by Rastin PLS bank branch. The owners of these certificates give a choice to Rastin PLS bank to use their deposits for granting to needy people graciously for a certain period and report his activities to the

\footnotetext{
${ }^{33}$ Joint Stock Company with Variable Capital (JSCVC): is a kind of fund in which the capital of fund varies along time through entering or exiting new shareholders and by changing their capital shares, or duration of sharing in fund. These funds can facilitate the operations of mutual funds, credit unions and bank sharing activities.

Bijan Bidabad, Joint Stock Company with Variable Capital (JSCVC), International Journal of Law and

Management, Vol. 56, Iss: 4, pp.302 - 310, 2014.

http://dx.doi.org/10.1108/IJLMA-09-2012-0031
} 
depositor and supervisory authorities. This certificate is used in Rastin Social Takaful (RST) subsystem.

28- Loan Certificate: is an anonym or named negotiable document with a defined face value and term that is issued by Rastin PLS bank. The owners of these certificates give a choice to the bank to use their deposits for extending interest-free loans to needy people for a specific period, and return the principal money back to the depositor after that period and report his activity to the depositor and supervisory authorities. This certificate is used in Rastin Social Takaful (RST) subsystem.

The complementary systems in Rastin Banking refer to innovations, systems, and complementary methods to solve specific shortages in the banking process as follows:
a. Rastin Certificate Market (RCM) ${ }^{34}$
b. Crowd Funding System (CFS) $)^{35}$
c. Operation Control and Monitor (OCM)
d. Collateral Registration System (CRS)
e. Serial Commitments Clearance (SCC $)^{36}$
f. Mortgage Securitization System (MSS $)^{37}$
g. Interbank Withdrawal Protocol (IWP) ${ }^{38}$
h. Non-Usury Scripless Security Settlement System (NSSSS) ${ }^{39}$
i. Money Laundering Detection System (MLD) ${ }^{40}$

All the above systems and instruments have different risk treatments and should be used by insurance measures to cover the risks of the projects failure and hedge the financial resources and benefits of the sides of the contracts.

\section{Insurance Products in Rastin Banking}

Financial activities of Rastin Banking need new insurance products and policies. In addition to prevailing insurances, some new insurance products were mentioned here. To safeguard the interests of depositors and to decrease risk and cover the probable losses of financial activities and also to alleviate confidence of the parties to Rastin PLS Banking contracts, some insurance coverage has been anticipated as follows:

1. Rastin Certificate Insurance: By paying a fee, bank or depositors can ask insurer companies to insure the total or a portion of the nominal value of their Rastin Certificate according to the request of the depositor or Rastin Certificate holder in charge and interest and name of the depositor or Rastin Certificate holder. Bank and insurance company can offer Rastin Certificate insurance rate and policy in Rastin Certificate Market web portal. Insuring Rastin Certificate is optional for the depositor in Rastin Banking.

2. Insurance of Market Value of Rastin Certificate: Rastin Certificate holder can insure his certificate against market price fluctuations at a higher price than nominal value in his charge and interest and name. This insurance is also optional.

\footnotetext{
${ }^{34}$ Bidabad, Bijan (2013) Rastin Certificate Market (RCM), Complementary System of Rastin Banking http://www.bidabad.com/doc/rastin-bank-rcm-en.pdf

${ }^{35}$ Bidabad, Bijan, Rastin Crowd Funding, 2014.

http://www.bidabad.com/doc/rcf-paper-en.pdf

${ }^{36}$ Bijan Bidabad, Serial Commitments Clearance (SCC) in Rastin Banking. International Journal of Law and Management, Vol. 57, Iss: 6, 2015, pp. 600-609, Emerald Group Publishing Limited. http://dx.doi.org/10.1108/IJLMA-02-2015-0007

${ }^{37}$ Bijan Bidabad, Mortgage Securitization System (MSS), A Complementary System of Rastin Banking. International Journal of Law and Management, Vol. 59 Iss: 3, 2017.

http://www.bidabad.com/doc/mss-paper-en.pdf

${ }^{38}$ Bidabad, Bijan, Mahmoud Allahyarifard. Interbank Withdrawal Protocol (IWP), Complementary System of

Rastin Banking, 2013.

http://www.bidabad.com/doc/iwp-paper-en.pdf

${ }^{39}$ Bidabad, Bijan, Mahmoud Allahyarifard. IT Based Usury Free Financial Innovations. Proceeding of ECDC 2010, 5th International Conference on e-Commerce in Developing Countries: with focus on e-Banking \& e-Insurance. ECDC 2010, 15-16 September 2010. http://www.bidabad.com/doc/non-usury-finance-it-en.pdf

${ }^{40}$ Bidabad, Bijan, (2017) Money Laundering Detection System (MLD), Complementary System of Rastin Banking, Journal of Money Laundering Control, Emerald Group Publishing Limited.
} 
3. Responsibility/Engineering Insurance: Responsibility/engineering insurance for covering probable losses of unexpected technical and human accidents during the execution of the project period is compulsory for entrepreneurs of Rastin PLS projects. The entrepreneur must buy corresponding insurance policies to cover the unexpected accidents in his charge and interest and name.

4. Insurance of Accidents Concerning the Article of Sharing: Entrepreneur must insure the article of sharing against natural calamities, fire accident, explosion, and other unexpected accidents at least equal to the amount of provided and used sources in charge of the project, and in interest and name of the bank. This insurance fee is an acceptable cost item for the project.

5. Collateral Insurance: Entrepreneur must insure his provided collaterals in charge of himself and interest and name of the bank at least equal to the value of bank share in the project during the project execution period. The entrepreneur must reinsure the collateral until the end of the execution period so that the collaterals should be insured for all times of the execution period.

6. Loss Margin Insurance: Entrepreneur can insure the project against probable loss equal to the amount of loss he expects. This insurance is optional or compulsory in various Rastin PLS Banking Subsystems. In the case of being compulsory, the entrepreneur is responsible for compensating the occurred losses according to the regulations of that subsystem if he had not bought the necessary insurance policy.

7. Profit Margin Insurance: In order to guarantee the probable profit margin, an entrepreneur can insure this margin in his charge and interest and name. This insurance is optional or compulsory according to different Rastin PLS Banking Subsystems applications.

8. Merchandise Transportation Insurance: Contract parties can insure the merchandises of the article of contract against probable risks of transportation, by mutual agreement. The assessment unit ${ }^{41}$ of the PLS department of the bank will determine the necessity of this insurance, according to the Financial Subsystem used. If the transported commodity, raw material, and intermediate goods comprise the interests of both parties, this insurance will be compulsory for both sender and receiver of the goods. The parties should provide this insurance policy at a specified time determined by the assessment unit in charge of sender and receiver and in name and interest of the bank.

9. Production Equipment and Installations Insurance: For better safety and performance of Rastin PLS Banking activity, an entrepreneur can insure his production equipment and installations against fire accidents, explosion, natural accidents, and calamities, and the risk concerns of the second party at his own charge, interest, and name. According to the applied Financial Subsystem, assessment unit of the PLS department of the bank will determine the compulsion or optionality of this insurance.

10. Product Quality Insurance: In order to ensure the quality of the produced goods and attracting buyers, an entrepreneur can insure the quality of his products according to conventional standards. The subject of this insurance policy is compensation of probable vital and financial losses to consumers, and a third party regarding the produced commodities because of unsafe, defective, and shortcomings processes of production. This insurance policy is optional.

11. Insurance of Commodity under Production: Entrepreneur must insure the producing commodity at least equal to the nominal value of the raw material bought or delivered, besides an insurer company confirmed by the bank for production period, in charge of entrepreneur and in name and interest of the bank.

12. Inventory Insurance: For better safeguarding of performance of Rastin PLS Banking activities, an entrepreneur can insure the raw materials and products inventories against risks of a fire accident, explosion, natural accidents and calamities, theft and also other party's risk concerns at his charge, name, and interest. According to the applied Financial Subsystem, the assessment unit of the PLS office of the bank will determine the compulsion or optionality of this insurance.

13. Production Limited Loss Insurance: If the market or estimated price of the construction project (at the end of construction period) is less than its cost price, "production limited loss insurance" can be used to compensate the loss.

41 - Assessment unit is a unit in PLS office of Rastin PLS bank which assesses the competence and capabilities of entrepreneur and his proposal. 
14. Transaction Limited Loss Insurance: Entrepreneur can insure the risk of transaction activities equal to the amount he is concerned about probable failure in his transaction activity at his own charge, name, and interest. If an entrepreneur does not insure this risk, he will bear the likely risk.

15. Transfer of Money Insurance: Bank can insure the risk of transfer of money equal to the amount he is concerned about probable failure in money transaction at his own charge, name, and interest. If the bank does not insure this risk, he will bear the probable risk.

It is possible to use coinsurance and reinsurance in all above cases. The insurer can use these kinds of insurances to pro rata the aftermaths of the occurred risks. In coinsurance, several companies will jointly insure a risk. This insurance is usually used to cover large risks such as fire accident or explosion and similar things in factories, and each insurer company bears a portion of the risk. In reinsurance, the first (direct) insurer company covers a portion of the risk, and the second insurer company will cover the remaining risk. In other words, the direct insurance company will insure a portion of the risk in another company.

Complementary insurances are a kind of insurance used by insuring companies to obtain more support for other accidents concerning the article insured. This is different from double insurance, which is referred to as multiple coverages of an item insured. By considering the applied Financial Subsystem, the assessment unit of the PLS office will define the necessity and kind of needed insurance before signing contracts. Several types of insurances as complementary insurances can be used. The necessary insurances for various Financial Subsystems are documented in Draft of Operational Bylaw of Rastin Banking ${ }^{42}$.

The listed insurance products have no conflict with well-known legal principles. Insurer companies can supply these insurance policies according to their actuary calculations to the bank, depositor, and entrepreneur. ${ }^{43}$

\section{References}

Bidabad, Bijan. (2014). New Operational Islamic Banking System, Volume One, Theoretical Foundations, LAP Lambert Academic Publishing, OmniScriptum GmbH \& Co. KG, ISBN: 978-3-659-54463-7.

Bidabad, Bijan. (2014). New Operational Islamic Banking System, Volume Two, Applicational Issues, LAP Lambert Academic Publishing, OmniScriptum GmbH \& Co. KG, ISBN: 978-3-659-55210-6.

Bidabad, Bijan, (2019) Economic-juristic analysis of usury in consumption and investment loans and contemporary jurisprudence shortages in exploring legislator commandments. International Journal of Islamic Business \& Management, 3(2), 1-15, 2019.

https://www.cribfb.com/journal/index.php/ijibm/article/view/275

http://www.bidabad.com/doc/reba-en.pdf

Bidabad, Bijan, (2019) Non-Usury Bank Corporation (NUBankCo), The Solution to Islamic banking. International Journal of Shari'ah and Corporate Governance Research, 2(1), 53-66.

https://www.cribfb.com/journal/index.php/ijscgr/article/view/276 http://www.bidabad.com/doc/NUBankCo-en.pdf

Bidabad, Bijan, Mahmoud Allahyarifard. (2019) IT role in fulfillment of Profit \& Loss Sharing (PLS) mechanism. Proceeding of the $3^{\text {rd }}$ International Islamic Banking and Finance Conference. International Journal of Islamic Banking and Finance Research, 3(2), 44-59.

https://www.cribfb.com/journal/index.php/ijibfr/article/view/274

http://www.bidabad.com/doc/english-pls-5.pdf

http://www.bidabad.com/doc/pls-it-en.ppt

Bidabad, Bijan, Mahmoud Allahyarifard. (2019) Implementing IT to Fulfill Profit \& Loss Sharing Mechanism.

\footnotetext{
${ }^{42}$ Bidabad, Bijan, Azarang Amirostovar, Saeed Abdollahi, Mahmoud Allahyarifard, Eskandar Pordel, Maryam Heidari, Alireza

Shafiei, Mohammad Ali Pourbehrouz. (2012) Draft of Rastin Banking Executive Regulation, Bank Melli Iran.

http://www.bidabad.com/doc/rastin-banking-regulation.pdf

${ }^{43}$ Erfani, Tofigh, (1992). Insurance Contract in Islam and Iran, Kayhan Publications. In Persian.
} 
Islamic Finance News (IFN), Vol. 3, Issue 3, 6, February 2006, pp. 11-15.

http://www.bidabad.com/doc/summery-pls-it-1.pdf

Bidabad, Bijan; Mahmoud Allahyarifard. (2019) Assets and Liabilities Management in Islamic Banking. International Journal of Islamic Banking and Finance Research, 3(2), 32-43.

https://www.cribfb.com/journal/index.php/ijibfr/article/view/272

http://www.bidabad.com/doc/alm-english.pdf

Bidabad, Bijan. (2019) Non-Usury Banking Fits the Change Strategy: The Solution to Revive the Economy. American Economic \& Social Review, 5(1), 49-61. https://www.cribfb.com/journal/index.php/aesr/article/view/283 http://www.bidabad.com/doc/PLS-paper-en-5.pdf

Bidabad, Bijan, Mahmoud Allahyarifard. (2019) The Executive Mechanism of Rastin Profit and Loss Sharing (PLS) Banking. 2009. Indian Journal of Finance and Banking, 3(1), 23-39. https://www.cribfb.com/journal/index.php/ijfb/article/view/308 http://www.bidabad.com/doc/PLS-banking-Executive-Mechanism.pdf http://www.bidabad.com/doc/pls-en.pptx

Bidabad, Bijan, Mahmoud Allahyarifard. (2019) IT-Based Usury-Free Financial Innovations. American Finance \& Banking Review, 4(1), 39-49. https://www.cribfb.com/journal/index.php/amfbr/article/view/289 http://www.bidabad.com/doc/non-usury-finance-it-en.pdf

Bidabad, Bijan, Mahmoud Allahyarifard. (2010) Usury-Free Bonds and Islamic Central Banking Monetary Instruments. http://www.bidabad.com/doc/Islamic-banking-bond-en.pdf

Bidabad, Bijan. (2019) Stabilizing Business Cycles by PLS Banking and Ethic Economics. International Journal of Shari'ah and Corporate Governance Research, 2(1), 67-82. https://www.cribfb.com/journal/index.php/ijscgr/article/view/284 http://www.bidabad.com/doc/pls-business-cycles-en.pdf

Bidabad, Bijan, Mahmoud Allahyarifard. (2010) Accounting Procedures for Profit and Loss Sharing (PLS) Banking. http://www.bidabad.com/doc/PLS-accounting-en.pdf

Bidabad, Bijan, Abul Hassan, Ben Ali Mohamed Sami, Mahmoud Allahyarifard. (2011) Interest-Free Bonds and Central Banking Monetary Instruments. International Journal of Economics and Finance. Vol. 3, no. 3, Aug 2011, pp.234-241. http://www.ccsenet.org/journal/index.php/ijef/article/download/11665/8300

Bidabad, Bijan, (2019) Fluctuations and Business Cycles Prevention by New Financial Instruments and Banking Structure Reform. International Journal of Accounting \& Finance Review, 4(1), 35-50, 2019. https://www.cribfb.com/journal/index.php/ijafr/article/view/282 http://www.bidabad.com/doc/Fluctuations-and-Cycles.pdf

Bidabad, Bijan, (2014) Mudarebah Financial Sharing (MFS). Journal of Islamic Economics, Banking and Finance, JIEBF, Volume - 10, Number - 1, January - April 2014, pp. 56-68. http://www.bidabad.com/doc/mfs-paper-en.pdf http://ibtra.com/pdf/journal/v10_n1_article3.pdf

Bidabad, Bijan, (2016) Joalah Financial Sharing (JFS). Journal of Islamic Economics, Banking and Finance, Volume-12, No. 1, January-March, 2016, pp. 33-48. http://www.bidabad.com/doc/jfs-paper-en.pdf http://ibtra.com/pdf/journal/v12_n1_article2.pdf 
Bidabad, Bijan, (2019) Interest-Free Treasury Bonds (IFTB). Interest-Free Treasury Bonds (IFTB). International Journal of Shari'ah and Corporate Governance Research, 2(2), 13-21. https://www.cribfb.com/journal/index.php/ijscgr/article/view/306 http://www.bidabad.com/doc/interest-free-t-bond-en.pdf http://www.bidabad.com/doc/iftb-en.pptx

Bidabad, Bijan, (2019) Interest-Free Treasury Bonds (IFTB), Islamic Finance and Legal Clarifications, 2011. International Journal of Islamic Business \& Management, 3(1), 21-29. http://www.bidabad.com/doc/interest-free-t-bond-feghi-en.pdf https://www.cribfb.com/journal/index.php/ijibm/article/view/258/353

Bidabad, Bijan, Abul Hassan, Ben Ali Mohamed Sami, Mahmoud Allahyarifard. (2011) Interest-Free Bonds Financial Innovation, A Monetary Instrument for Economy at Crisis. Journal of Economic Cooperation and Development (JECD). 32, 1, 2011, 55-70. http://www.sesric.org/jecd/jecd_articles/ART10102201-2.pdf

Bidabad, Bijan, (2011) Deposits and Loans Interest Rates Lag Structure and Business Cycles (Case Study of United States). http://www.bidabad.com/doc/Interest-Rates-Lags-and-Cycles.pdf

Bidabad, Bijan, (2019) Installment Financial Sharing (IFS): A Financial Subsystem of Rastin PLS Banking. International Journal of Islamic Banking and Finance Research, 3(1), 28-42. https://www.cribfb.com/journal/index.php/ijibfr/article/view/267 http://www.bidabad.com/doc/ifs-paper-en.pdf

Bidabad, Bijan, Abul Hassan, (2019) Does The Interest Rate Form Business Cycle?, 2011. International Journal of Accounting \& Finance Review, 4(1), 29-34. https://www.cribfb.com/journal/index.php/ijafr/article/view/281 http://www.bidabad.com/doc/interest-rate-cycle.pdf

Bidabad, Bijan, (2014) Rent Financial Sharing (RFS). Journal of Islamic Economics, Banking and Finance, Vol. 10 No. 2, pp.: 38-53, April-June 2014. http://www.bidabad.com/doc/rfs-paper-en.pdf http://ibtra.com/pdf/journal/v10_n2_article2.pdf

Bidabad, Bijan, (2015) Rastin Social Takaful (RST). Journal of Islamic Economics, Banking and Finance, JIEBF, Volume - 11, Number - 1, January - March 2015, pp.: 13-23. http://ibtra.com/pdf/journal/v11_n1_article1.pdf http://www.bidabad.com/doc/rst-paper-en.pdf

Bidabad, Bijan, (2017) Mortgage Securitization System (MSS), A Complementary System of Rastin Banking. International Journal of Law and Management (IJLMA), Vol. 59 Issue: 6, pp.778-783, 2017. https://doi.org/10.1108/IJLMA-05-2016-0045 http://www.bidabad.com/doc/mss-paper-en.pdf

Bidabad, Bijan, (2019) Bail Financial Sharing (BFS): A Financial Subsystem of Rastin PLS Banking. International Journal of Islamic Banking and Finance Research, 3(1), 21-27. https://www.cribfb.com/journal/index.php/ijibfr/article/view/266 http://www.bidabad.com/doc/bfs-paper-en.pdf

Bidabad, Bijan, (2015) Rastin Personal Security (RPS). Journal of Islamic Economics, Banking and Finance, JIEBF, Volume - 11, Number - 2, April - June 2015, pp. 47-61. http://ibtra.com/pdf/journal/v11_n2_article3.pdf http://www.bidabad.com/doc/rps-paper-en.pdf

Bidabad, Bijan, (2014) Joint Stock Company with Variable Capital (JSCVC), International Journal of Law and 
Management (IJLMA), Vol. 56, Iss: 4, pp.302 - 310, 2014.

http://dx.doi.org/10.1108/IJLMA-09-2012-0031

http://www.bidabad.com/doc/vjsc-paper-en.pdf

Bidabad, Bijan, (2013) Rastin Profit and Loss Sharing (PLS) Base System. Journal of Islamic Economics, Banking and Finance, pp. 32-57, Vol. 9, No. 4, Oct-Dec 2013.

http://ibtra.com/pdf/journal/v9_n4_article2.pdf

http://www.bidabad.com/doc/pls-base-en.pdf

Bidabad, Bijan, (2017) Money Laundering Detection System (MLD), A Complementary System of Rastin Banking, Journal of Money Laundering Control, Vol. 20 Issue: 4, pp. 354-366, 2017.

https://doi.org/10.1108/JMLC-04-2016-0016

http://www.bidabad.com/doc/mld-paper-en.pdf

Bidabad, Bijan, (2014) General Characteristics of Rastin Banking. Proceeding of the 3rd International Conference on Economics, Political, Law and Fiscal Sciences (EPLS '14), World Scientific and Engineering Academy and Society (WSEAS). Transilvania University of Brasov, Brasov, Romania, June 26-28, 2014.

http://www.bidabad.com/doc/rastin-bank-general-en.pdf

http://www.bidabad.com/doc/rastin-bank-general-en.ppt

Bidabad, Bijan, (2013) A glance at Rastin Banking, 2013.

http://www.bidabad.com/doc/rastin-bank-glance-en.pdf

Bidabad, Bijan, Rastin Banking, New Operational Islamic Banking System (A bird's eye view). Islamic Finance News (IFN), Vol. 10, Issue: 28, 17, July, 2013, pp. 16-18.

http://www.bidabad.com/doc/rastin-bank-bird-eye-view-en.pdf

Bidabad, Bijan, (2019) Islamic Monetary Policy, 2013. International Journal of Islamic Banking and Finance Research, 3(2), 1-16, 2019.

https://www.cribfb.com/journal/index.php/ijibfr/article/view/269

http://www.bidabad.com/doc/islamic-monetary-policy-en.pdf

Bidabad, Bijan, (2019) Rastin Certificate Market (RCM), Complementary System of Rastin Banking, 2013. International Journal of Islamic Business \& Management, 3(1), 35-43.

https://www.cribfb.com/journal/index.php/ijibm/article/view/260

http://www.bidabad.com/doc/rastin-bank-rcm-en.pdf

Bidabad, Bijan, (2019) Sovereign Wealth Fund Asset and Liability Management by Rastin Banking Financial Instruments (Rastin Certificates and Rastin Swap Bonds). American Finance \& Banking Review, 4(1), 1-16. https://www.cribfb.com/journal/index.php/amfbr/article/view/285 http://www.bidabad.com/doc/swf-alm-en.pdf http://en.ndf.ir/international-conference/nic-2013/conference-full-paper.aspx

Bidabad, Bijan, Mahmoud Allahyarifard, (2019) Interbank Withdrawal Protocol (IWP), Complementary System of Rastin Banking. International Journal of Islamic Business \& Management, 3(1), 30-34.

https://www.cribfb.com/journal/index.php/ijibm/article/view/259

http://www.bidabad.com/doc/iwp-paper-en.pdf

Bidabad, Bijan, Roohollah Mohammadi; Mahshid sherafati, (2013) Social Takaful and Qard ul-Hassanah Banking Convergences (A Functional Approach), Journal of Applied Science and Agriculture (JASA) November issue 2013.

http://www.bidabad.com/doc/takaful-en.pdf

Bidabad, Bijan, (2019) Change Management of Banking System at National Level by Rastin Banking (Knowledge Management, Empowerment, Prune and Graft, and Apprenticeship). Review of Behavioral Aspect in Organizations and Society, 1(1), 57-70. 
https://doi.org/10.32770/rbaos.vol157-70

http://www.bidabad.com/doc/change-banking-en.pdf

http://www.bidabad.com/doc/change-banking-en.pptx

Bidabad, Bijan, (2014) Insurance Products in Rastin Banking, 2014.

http://www.bidabad.com/doc/rastin-insurance-en.pdf

Bidabad, Bijan, (2019) Rastin Crowdfunding (RCF): A Financial Subsystem of Rastin Banking. International Journal of Islamic Banking and Finance Research, 3(1), 13-20. https://www.cribfb.com/journal/index.php/ijibfr/article/view/265 http://www.bidabad.com/doc/rcf-paper-en.pdf

Bidabad, Bijan, (2019) Rastin Group Funding (RGF): A Financial Subsystem of Rastin Banking. International Journal of Islamic Banking and Finance Research, 3(1), 43-48.

https://www.cribfb.com/journal/index.php/ijibfr/article/view/268

http://www.bidabad.com/doc/rgf-paper-en.pdf

Bidabad, Bijan, Mahshid Sherafati, (2019) Bank Information Disclosure, Financial Transparency and Corporate Governance in Rastin Banking, International Journal of Shari'ah and Corporate Governance Research, 2(1), 113.

https://www.cribfb.com/journal/index.php/ijscgr/article/view/257

http://www.bidabad.com/doc/shafafiyat-en.pdf

Bidabad, Bijan, Mahshid Sherafati, (2015) Financial Transparency, Governance and Public Disclosure for Entrepreneur (Financial Resource Receiver) in Rastin Banking System. Tehran, Iran, 2015.

http://www.bidabad.com/doc/transparency-entrepreneur-en.pdf

Bidabad, Bijan, Azarang Amirostovar, Mahshid Sherafati, (2019) Financial Transparency, Corporate Governance and Information Disclosure of the Entrepreneur's Corporation in Rastin Banking. International Journal of Law and Management (IJLMA), Vol:59, Iss:5, pp.636-651, 2017.

https://doi.org/10.1108/IJLMA-01-2016-0003

Bidabad, Bijan, Saeid Abdollahi, Mahshid Sherafati, Rohollah Mohammadi, (2019) Proposed Regulations for Enforcement of Purports of Binding Banking Documents in Rastin Banking. International Journal of Small and Medium Enterprises, 2(1), 23-49.

https://www.cribfb.com/journal/index.php/ijsmes/article/view/321

http://www.bidabad.com/doc/rastin-bank-ejraye-asnad-en.pdf

Bidabad, Bijan, Saeed Abdollahi, Mahshid Sherafati, (2017) Enforcement of the Purports of Binding Banking Documents in Rastin Banking - Part I. International Journal of Law and Management (IJLMA), Vol:59, Iss:1, pp. 52-65, 2017.

https://doi.org/10.1108/IJLMA-07-2015-0041

Bidabad, Bijan, Saeed Abdollahi, Mahshid Sherafati, (2017) Enforcement of the Purports of Binding Banking Documents in Rastin Banking - Part II. International Journal of Law and Management (IJLMA), Vol:59, Iss:2, pp.178-191, 2017.

https://doi.org/10.1108/IJLMA-10-2015-0055

Bidabad, Bijan, Mahshid Sherafati, (2017) Sustainable Financing and Anti-Squandering Measures in Rastin Banking. International Journal of Law and Management (IJLMA), Vol: 59, Issue: 6, pp. 939-949, 2017. https://doi.org/10.1108/IJLMA-04-2016-0037

http://www.bidabad.com/doc/esraf-bank-resource-en.pdf

Bidabad, Bijan, (2015) Serial Commitments Clearance (SCC) in Rastin Banking. International Journal of Law and Management (IJLMA), Vol. 57, Iss: 6, 2015, pp. 600-609.

http://dx.doi.org/10.1108/IJLMA-02-2015-0007 
http://www.bidabad.com/doc/scc-paper-en.pdf

Bidabad, Bijan, (2019) Rastin Swap Deposit (RSD): A Financial Account of Rastin Banking. International Journal of Islamic Banking and Finance Research, 3(2), 17-23.

https://www.cribfb.com/journal/index.php/ijibfr/article/view/270

http://www.bidabad.com/doc/rsd-paper-en.pdf

Bidabad, Bijan, (2019) Rastin Swap Card (RSC): A Financial Instrument of Rastin Banking. International Journal of Islamic Banking and Finance Research, 3(2), 24-31.

https://www.cribfb.com/journal/index.php/ijibfr/article/view/271

http://www.bidabad.com/doc/rsc-paper-en.pdf

Bidabad, Bijan, Mahshid Sherafati, (2016) Operational Ethical Banking in Rastin Banking (Professional Ethics, Audit, Inspection, Control, Monitoring and Preservation). International Journal of Law and Management (IJLMA), Vol: 58, Iss: 4, 2016, pp. 416-443.

http://dx.doi.org/10.1108/IJLMA-07-2015-0037

http://www.bidabad.com/doc/rastin-ethic-banking-en.pdf

Bidabad, Bijan, Mahmoud Allahyarifard, Mahshid Sherafati, (2019) Rastin Partnership Accounting, Part I: General Procedure, Journal of Islamic Accounting and Business Research.

http://www.bidabad.com/doc/rastin-partnership-accounting-I-en.pdf

https://doi.org/10.1108/JIABR-04-2016-0049

Bidabad, Bijan, (2019) Rastin Partnership Accounting, Part II: Mudarabah Financial Sharing (MFS). http://www.bidabad.com/doc/rastin-partnership-accounting-II-en.pdf

Bidabad, Bijan, (2019) Rastin Partnership Accounting: Part III: Instalment Financial Sharing (IFS). http://www.bidabad.com/doc/rastin-partnership-accounting-III-en.pdf

Bidabad, Bijan, Abul Hassan, (2017) Dynamic Lag Structure of Deposits and Loans Interest Rates and Business Cycles Formation. Journal of Financial Regulation and Compliance, Vol. 25 Issue: 2, pp.114-132, 2017. http://dx.doi.org/10.1108/JFRC-09-2016-0078

Bidabad, Bijan, (2018) General Regulatory Framework in Rastin Profit and Loss Sharing Banking (Part IOperational Context). Journal of Business and Finance in Emerging Markets, JBFEM, [S.1.], v. 1, n. 1, p. 11-26, may 2018. ISSN 2580-5568.

https://doi.org/10.32770/jbfem.vol111-26

http://www.bidabad.com/doc/rastin-regulatory-en-I.pdf

Bidabad, Bijan, (2018) General Regulatory Framework in Rastin Profit and Loss Sharing Banking (Part II-Legal Groundwork). Journal of Business and Finance in Emerging Markets, JBFEM, JBFEM, [S.1.], v. 1, n. 2, p. 109126, nov. 2018. ISSN 2580-5568.

https://doi.org/10.32770/jbfem.vol1109-126

http://www.bidabad.com/doc/rastin-regulatory-en-II.pdf

Bidabad, Bijan, (2018) General Regulatory Framework in Rastin Profit and Loss Sharing Banking (Part IIIAuxiliary Provisions). Journal of Business and Finance in Emerging Markets, JBFEM, May 2019, Vol 2, No. 1, pp. 51-65. ISSN 2580-5568.

https://doi.org/10.32770/jbfem.vol251-66

http://www.bidabad.com/doc/rastin-regulatory-en-III.pdf

Bidabad, Bijan, Rohollah Mohammadi, Mahshid Sherafati, (2019) Organizational Design and Rules in Rastin Profit and Loss Sharing Banking. International Journal of Small and Medium Enterprises, 2(1), 9-22.

https://www.cribfb.com/journal/index.php/ijsmes/article/view/320

http://www.bidabad.com/Organizational-structure-paper-en.pdf 
Bidabad, Bijan, Azarang Amirostovar, Saeid Abdollahi, Mahmoud Allahyarifard, Eskandar Pordel, Maryam Heidari, Alireza Shafiei, Mohammad Ali Pourbehrouz (2012) Draft of Rastin Banking Bill, Bank Melli Iran. http://www.bidabad.com/doc/rastin-banking-bill.pdf

Bidabad, Bijan, Azarang Amirostovar, Saeed Abdollahi, Mahmoud Allahyarifard, Eskandar Pordel, Maryam Heidari, Alireza Shafiei, Mohammad Ali Pourbehrouz. (2012) Draft of Rastin Banking Executive Regulation, Bank Melli Iran.

http://www.bidabad.com/doc/rastin-banking-regulation.pdf

Erfani, Tofigh, (1992) Insurance Contract in Islam and Iran, Kayhan Publications. In Persian

Moin, Mohammad (1971) Moin Persian Dictionary. AmirKabir Publishing Institute. In Persian.

Mehr, Robert I., (1985) Principles of Insurance. Richard D Irwin; $8^{\text {th }}$ edition.

Salehi, Jan Ali Mahmoud, (2002). Insurance law. Bimeh Markazi, Iran. Training and Publication Department. In Persian.

Vaughn, Emmett J. (1989) Fundamentals of Risk and Insurance. $5^{\text {th }}$ edition, Wiley.

\section{Copyrights}

Copyright for this article is retained by the author(s), with first publication rights granted to the journal. This is an open-access article distributed under the terms and conditions of the Creative Commons Attribution license (http://creativecommons.org/licenses/by/4.0/). 